\title{
Description of Gomphothidium gen. nov., with light and scanning electron microscopy: A New Freshwater Monoraphid Diatom Genus from Asia
}

\author{
John Patrick Kociolek ${ }^{1}$, Qingmin $\mathrm{You}^{2}$, Pan $\mathrm{Yu}^{2}$, Yanling $\mathrm{Li}^{3}$, Yanlu WAng ${ }^{2}$, Rex \\ LowE $^{4} \&$ Quanxi WANG ${ }^{2}$
}

\author{
${ }^{1}$ Museum of Natural History and Department of Ecology and Evolutionary Biology, University of Colorado, \\ Boulder, CO, USA \\ ${ }^{2}$ College of Life Sciences, Shanghai Normal University, Shanghai, People's Republic of China \\ ${ }^{3}$ Institute for Ecological Research and Pollution Control of Plateau Lakes, School of Ecology and Environmental \\ Science, Yunnan University, Kunming 650500, People's Republic of China \\ ${ }^{4}$ Department of Biological Sciences, Bowling Green State University, Bowling Green, OH, USA
}

\begin{abstract}
We describe a new genus of monoraphid diatom based on Achnanthidium ovatum T. Watanabe et Tuji in Watanabe et al., a species described originally from Japan. We encountered this species from Yunnan Province in the southwestern part to eastern China, as well as in Luding, Sichuan Province and Xianju, Zhejiang Province, in pristine lotic environments. The species differs from the genus Achnanthidium by being asymmetrical to the transapical axis and has a pseudoseptum at the poles of the interior of the raphe valve which is fused with each helictoglossa. Moreover, a distinct group of condensed striae can be found at the narrower pole ('footpole') of the raphe valve. This appears to be the only known genus of freshwater monoraphid diatoms that is restricted to a single continent.
\end{abstract}

Key words: New Genus, Monoraphid diatoms, SEM, biogeography, Achnanthidiaceae, China, Asia

\section{INTRODUCTION}

Diatoms that have a single raphe system on their frustules (termed 'monoraphid diatoms') represent a diverse assemblage of species that totals over 2,000 taxa assigned to over 15 genera (KocIOLEK et al. 2019). These genera occur within at least 5 distinct lineages of biraphid diatoms, representing independent losses of the raphe system on one of the valves (THOMAs et al. 2016; KocIOLEK et al. 2019). The monoraphid diatoms occur in marine ecosystems and freshwaters, and they all are symmetrical about the apical and transapical axes. An exception to this could be the genus Sinoperonia Kociolek, Liu, Glushchenko et Kulikovskiy in LIU et al. (2018), which belongs to the Eunotiales and forms predominantly monoraphid frustules but can also form biraphid and araphid frustules.

Over the last 30 years, there has been a large body of work revising the freshwater monoraphid diatoms, going from recognizing basically two genera in freshwaters (Achnanthes and Cocconeis; see Hustedt 1930; PATRICK
\& Reimer 1966; Krammer \& LANGe-Bertalot 1991), to recognizing ca. 13 freshwater genera (Round \& BuKhTIYAROVA 1996; ROUND \& BASSON 1997; KRAMMER \& LANGE-Bertalot 2004; Wojtal 2013; KuliKovskiY et al. 2013; KULIKOvsKIY et al. 2015; see KocioleK et al. 2015a) worldwide. Even with this relatively recent revisionary work and the proposal of new genera, there are no known freshwater genera of monoraphids that are endemic to a single continent (KocIOLEK, 2019).

In the last ten years there has been renewed interest in the biodiversity of freshwater diatoms from China, with several new genera (e.g. Tibetiella Li et al. 2010; Gomphosinica KocIOLEK et al. 2015; Edtheriotia KocioleK et al. 2016) and many new species described from across the country (KocioleK et al., in review). In the present report we use light and scanning electron microscopy to describe a new freshwater monoraphid diatom genus that occurs across the China, from Yunnan to Sichuan to Zhejiang Provinces as well as in Japan. Unique symmetry and other features of the valve distinguish this new species from all other freshwater monoraphid genera. 


\section{Material ANd Methods}

Diatom samples were collected from the western Sichuan plateau and National Forest Park of Xianju, Zhejiang. The western Sichuan plateau is located in the SE edge of the Qinghai-Tibet plateau, and has high elevation mountains. Forest Park of Xianju is located in the southeast of Zhejiang. Diatom samples were removed from stones, plant roots and other substrates in lentic and lotic systems using tweezers or a knife, and from sediments using a turkey baster. Sample information is listed in Table 1, including location of samples, habitat, and elevations. Water temperature, $\mathrm{pH}$ and conductivity were measured using a YSIPro Plus multiparameter meter (YSI Inc., Yellow Springs, OH., U.S.A.).

In the laboratory, a. Microwave Accelerated Reaction System (Model MARS, CEM Corporation, Mathews, NC, USA) was used to digest samples, following the procedures of PARR et al. (2004) and modified as described in You et al. (2015). Cleaned diatoms were mounted in Naphrax ${ }^{\circledR}$ (Robert Charles laboratories Ltd., UK) for light microscopy (LM). LM observations were made with an Olympus BX-53 microscope fitted with differential interference contrast (DIC) optics and an Olympus DP-80 digital camera. For Scanning Electron Microscopy observations, samples were observed with a SU8010 field emission SEM (Hitachi Corporation, Tokyo, Japan). Slides and cleaned material are preserved at SHNU and at COLO. Diatom images were compiled with Photoshop 6.0 software (Adobe Systems Incorporated, USA).

For the Yunnan samples, six samples were collected from high mountain lakes on the Yunnan Plateau (26 $37^{\prime} 44.8^{\prime \prime}-26^{\circ} 38^{\prime} 29.89^{\prime \prime} \mathrm{N}$, 99 42'33.1"-9943'31.9"E), in September and October, 2006 and 2007 (Table 1). The samples were collected by scraping rocks and then fixing the samples in 5\% formalin. Organic matter was removed according to the method of BATTARBEE (1987). These samples are archived at Yunnan University. Permanent diatom slides were made with Naphrax. Diatoms were identified using oil immersion at $1000 \times$ magnification with an Olympus microscope (BX51-DIC). Cleaned material for SEM analysis was air-dried onto cover glasses, mounted onto stubs, and coated with $20 \mathrm{~nm}$ of Au. Samples were examined and photographed using a Leo 1530 SEM. Cleaned material and slides are preserved at the Institute for Ecological Research and Pollution Control of Plateau Lakes, School of Ecology and Environmental Science, Yunnan University, Kunming, P. R. China. Environmental parameters were measured, including conductivity and $\mathrm{pH}$ (measured by using YSI 6600 Multiparameter Instrument).

\section{RESULTS}

Class Bacillariophyceae Haeckel emend. MedLin \& KaCZMARSKa (2004)

Subclass Bacillariophycidae D.G.Mann in Round et al. (1990)

Order Cymbellales D.G.Mann in Round et al. (1990) Family Achnanthidiaceae D.G.Mann in Round et al. (1990)

\section{Gomphothidium Kociolek et al., gen. nov.}

Description: Frustules flexed about the transapical axis, with one raphe system. Valves narrowly linear-lanceolate, clavate, asymmetrical about the transapical axis.

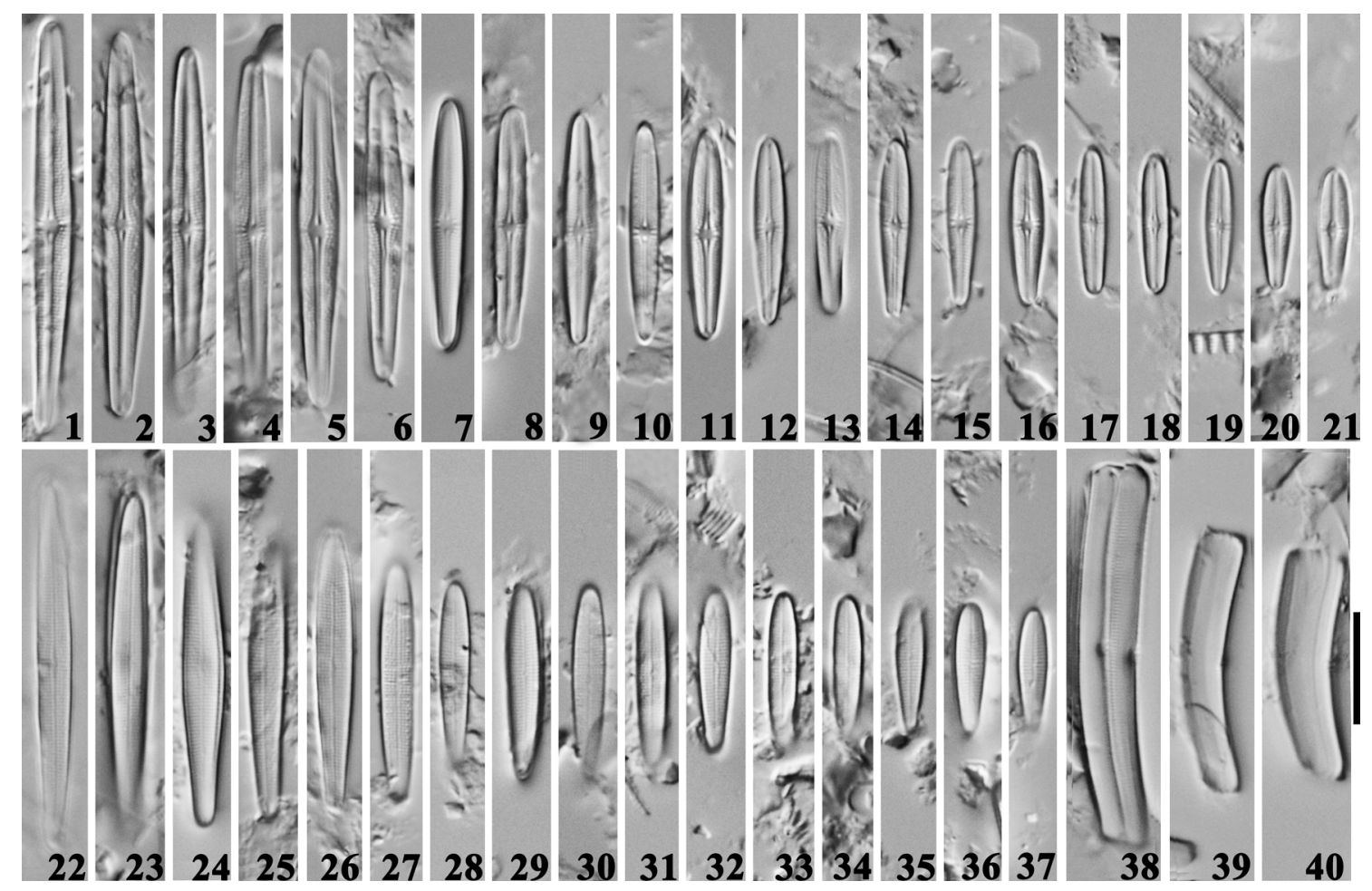

Figs 1-40. LM, Gomphothidium ovatum: (1-21) valve views of raphe valves; (22-37) valve views of rapheless valves; (38-40) girdle view of frustules. Scale var $10 \mu \mathrm{m}$. 
Raphe valve with axial area narrow, raphe with dilated external proximal raphe ends. External distal raphe ends straight, not extending onto the valve mantle. Striae fine, radiate, coarse around the central area, compressed at the footpole. Internally, raphe with proximal raphe ends deflected in opposite directions. Helictoglossae thickened, connected to laterally-expanded pseudosepta at the poles. Areolae with hymenate occlusions on the valve face and mantle. Rapheless valve with narrow, straight central sternum, striae radiate, spaced evenly along the valve face. Internally, areolae with hymenate occlusions, extending around the face and mantle.

Type species of the genus: Gomphothidium ovatum (T.Watanabe et Tuji in WaTANABE et al. 2008: 34) Kociolek et al. comb. nov.

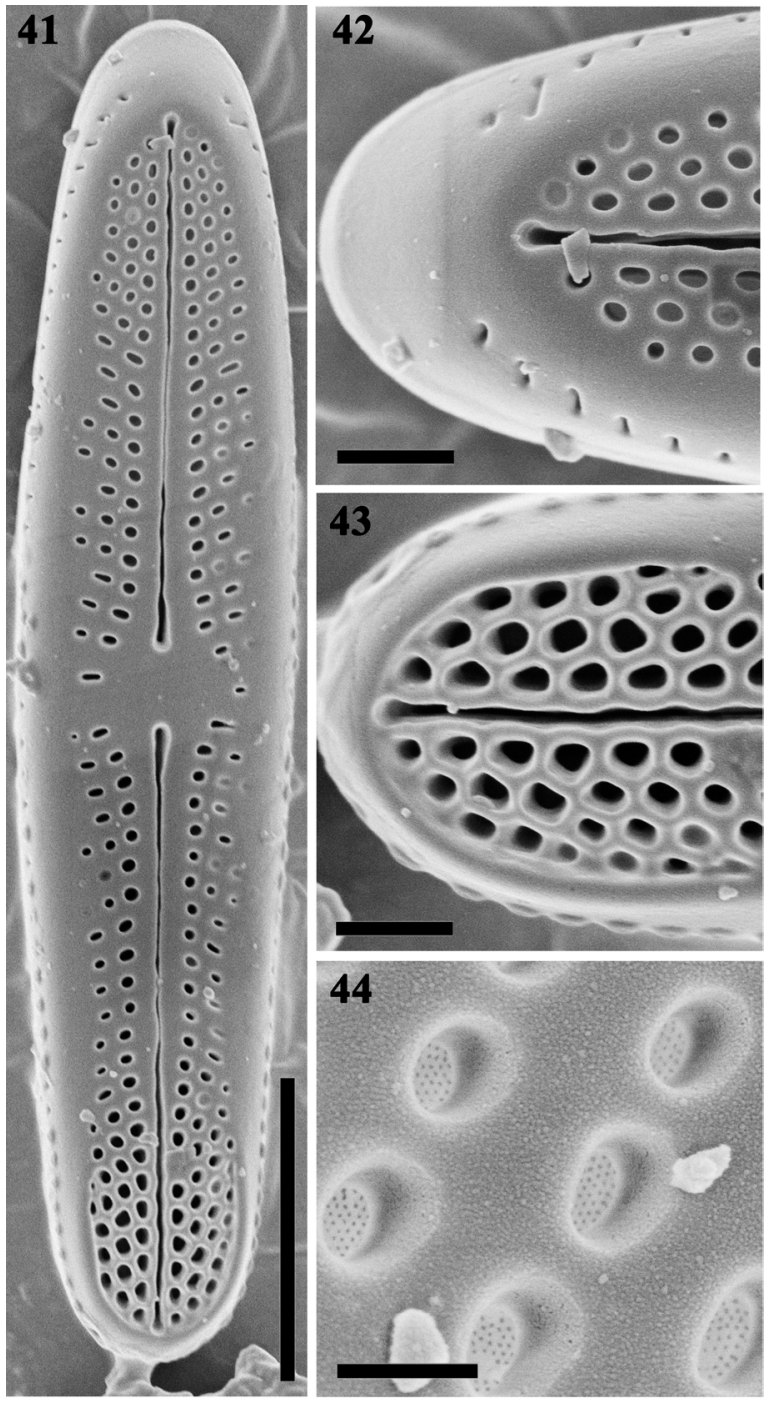

Figs 41-44. SEM, Gomphothidium ovatum, raphe valves, external views: (41) entire valve view. Raphe is straight, with dilated proximal ends. There is a higher concentration of striae and areolae at the footpole. A single row of areolae is evident on the mantle. (42) headpole with smaller areolae. (43) footpole. Areolae are larger than the rest of the valve and denser. (44) view into areolae with internal hymens evident. Scale bar $5 \mu \mathrm{m}$ (41), $0.5 \mu \mathrm{m}(42,43), 0.2 \mu \mathrm{m}$ (44).
Basionym: Achnanthidium ovatum T.Watanabe et Tuji in WatanaBE et al. (2008): Epilithic diatom assemblages and two new species Achnanthidium ovatum and Gomphonema yakuensis from Yaku-shima Island, Kagoshima Prefecture, Japan. - Diatom 24: 34, figs 2-25.

In LM, the valves of G. ovatum are asymmetrical to the transapical axis, with the upper half of the valve being broader than the lower half. Valves are clavate or lanceolate with round ends. Valves are 9.0-37.5 $\mu \mathrm{m}$ long and 2.5-3.5 $\mu \mathrm{m}$ wide. Proximal raphe ends distinct, teardrop-shaped (Figs 1-21). Raphe valves with a linear axial area expanding slightly towards the center. Striae are most indistinct, easier to resolve in the middle part of valve where a few stria rows become resolvable due to a wider spacing (Figs 1-21). Rapheless valve with a linear axial area (Figs 22-37). Striae on the rapheless valves are indistinct (Figs 22-37). Frustules in girdle view are distinctly bent, nearly $\mathrm{V}$-shaped (Figs 38-40).

In the SEM, the raphe valve with a narrow lanceolate axial area and an elliptic-lanceolate central area (Figs $41,45,50)$. The rapheless valve with a linear axial area and no distinct central area (Figs 51, 52). Externally, on the raphe valve the distal raphe fissures straight to very slightly deflected, while the central raphe endings dilated and teardrop-shaped (Figs 41, 50). At the headpole, areolar openings distinctly larger compared to the opposite apex. Internally, distal raphe ends slightly curved towards opposite sides. Thickenings on either side of the raphe terminus, but helictoglossae appear merged into the pseudosepta, which appear shelf-like at both apices (Figs 45-47). Pseudosepta not present on the rapheless valves (Fig. 52). Internal proximal raphe endings curved in opposite directions. Striae radiate throughout on both valves (Figs 41, 48). Stria density $31-34$ in $10 \mu \mathrm{m}$ at the valve center and up to 41 in $10 \mu \mathrm{m}$ near apices of raphe valve, $28-32$ in $10 \mu \mathrm{m}$ at the valve center and up to 36 in $10 \mu \mathrm{m}$ near apices on the rapheless valve. Areolae external openings round, or transapically elongated, whereas internal openings transversely elliptical (Figs 41-44). Each stria in the middle part of the raphe valve composed of 1-2 (usually 2) areolae (Fig. 44). Each stria towards the base composed of 3-4 larger areolae (Figs $41,43)$. Each stria in the middle part of the rapheless valve composed of 3-4 areolae (Figs 51-52). Around the central areas of raphe valves, striae more widely spaced and shortened; sometimes very short marginal striae (composed of 1-2 areolae) present. A row of slit-like areolae present on the valve mantle (e.g. Figs 50, 51).

\section{Discussion}

This new genus of monoraphid diatoms has fine hymenate occlusions and internal proximal raphe ends being deflected in opposite directions, and both of these features suggest it is closely allied with Achnanthidium (Yu et al. 2018, 
2019). There are several other features that distinguish Gomphothidium from Achnanthidium, however, which argue for recognition of this taxon as a separate genus. In addition to the valve asymmetry, Gomphothidium has a distinct concentration of areolae at the narrower end of the valve ('footpole') bordered by a thickened rim. The areolae are suggestive of an apical pore field, but because the samples studied here were cleaned immediately, we cannot be sure if these pores function in mucilage secretion, as is the case for other apical pore field-bearing diatoms such as Cymbella C.A.Agardh, Gomphonema C.G.Ehrenberg and Gomphonella Rabenhorst (Krammer \& Lange-Bertalot 1986; KocioleK et al. 2015b). Internally, raphe valves of Gomphothidium have internally-projected pseudosepta at both poles. At the broader pole ('headpole') the thickening is distinct and broadened beyond where the helictoglossa connects to it. At the narrower end of the valve the thickening is smaller. The helictoglossae are attached, and reduced in size as compared to species in Achnanthidium. These features, taken together, and compared to distinctions made between other monoraphid genera such as valve shape (to separate Psammothdium Bukhtiyarova et Round from Achnanthidium; but see MoNNIER et al. 2007), and cavum number (to separate Gliwicizia Kulikovskiy et al. from Planothidium), support the proposal of a new genus.

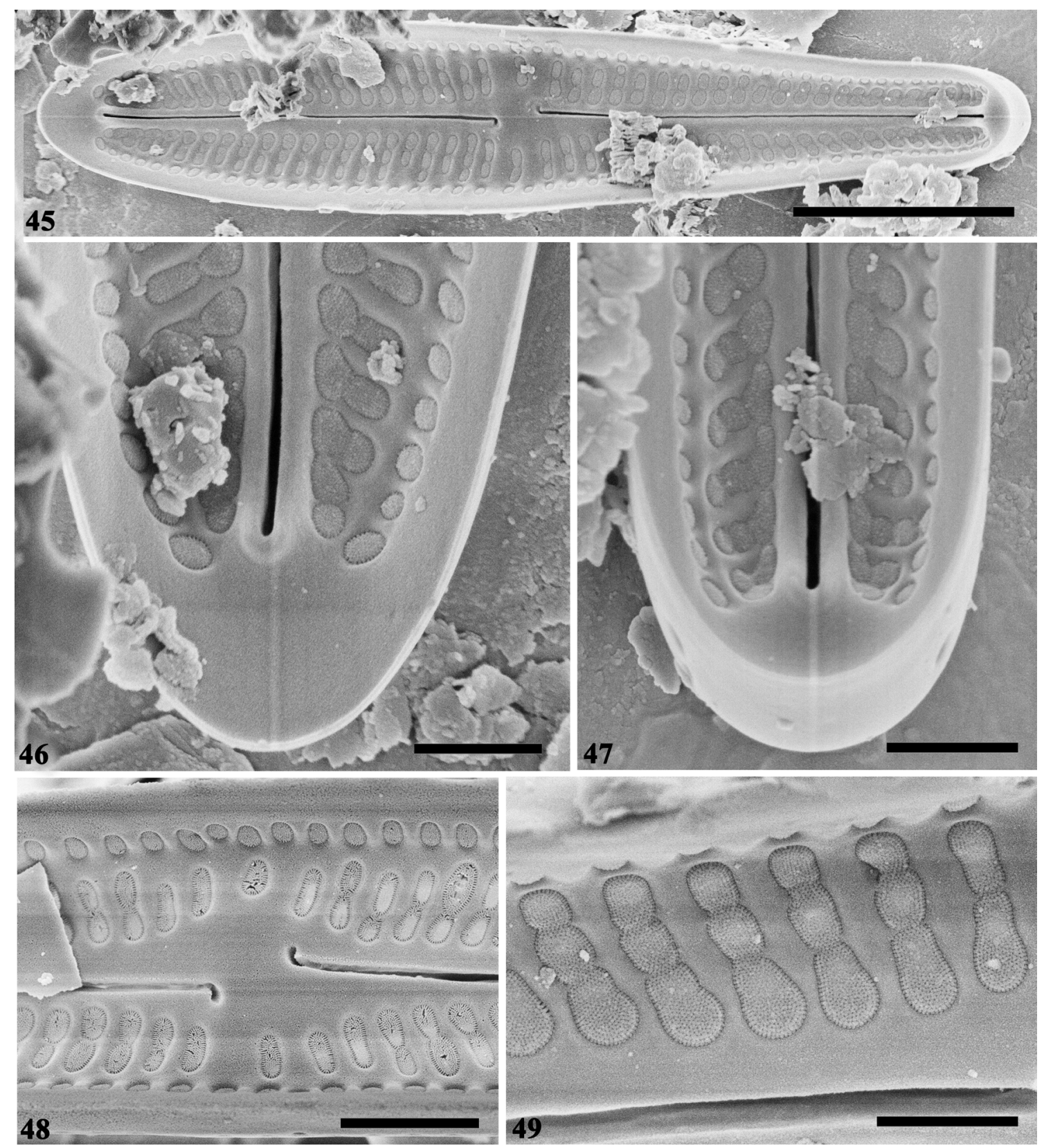

Figs 45-49. SEM, Gomphothidium ovatum, raphe valves, internal views: (45) valve view showing asymmetry about the apical axis. In the central area proximal raphe ends are deflected opposite to one another. Pseudosepta are evident at the poles. (46) headpole, with distinct pseudoseptum attached with the helictoglossa. (47) footpole, with pseudoseptum attached to indistinct helictoglossa. (48) central area with proximal raphe ends curved opposite to one another. (49) view are areolae with hymenate occlusions. Scale bar $3 \mu \mathrm{m}(45), 0.5 \mu \mathrm{m}(46,47,49), 1 \mu \mathrm{m}(48)$. 
Within Achnanthidium, however, three morphological groups have been identified, recognized by their distinctive features of flexure of the external distal raphe ends and areolar structure, the $A$. minutissimum complex, the A. pyrenaicum complex and the $A$. exiguum complex. Members of the $A$. minutissimum complex have straight external distal raphe endings and round to elliptical areolae, members of the $A$. pyrenaicum complex have external distal raphe fissures deflected in the same direction and with lineate areolae, and members of the A. exiguum complex have external distal raphe fissures deflected in the opposite directions (WOJTAL et al. 2011; PÉRÈS et al. 2012; PÉRÈs et al. 2014; KARTHICK et al. 2017). Based on this breakdown of the genus Achnanthidium, Gomphothidium most resemble members of the A. minutissimum group (NovaIs et al. 2015). There here are no formal analyses, however, to support the idea that these distinctions reflect phylogenetic affinities.

Gomphothidum may be endemic to Asia. The specimens on which we base our observations are from China, and these occurred from Yunnan eastward to Sichuan and to Zhejiang Provinces. The specimens of G. obtusum were described originally from Yakushima Island, Kagoshima Prefecture, Japan (WATANABE et al. 2008). The original authors of this species suggested that although it was

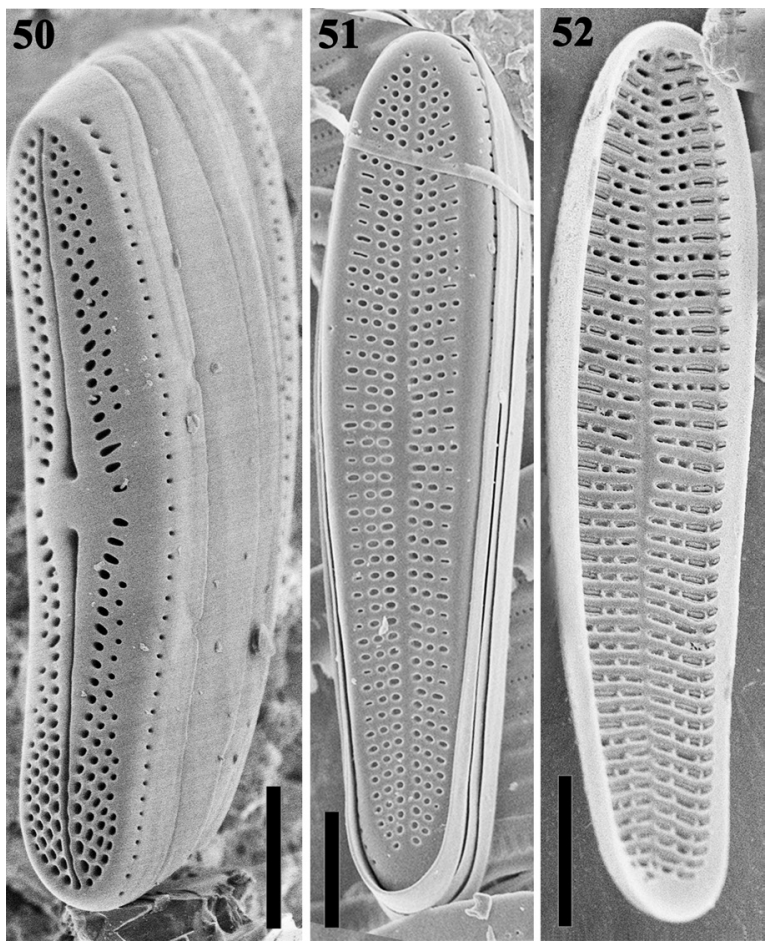

Figs 50-52. SEM, Gomphothidium ovatum: (50) external view of raphe valve. Flexed nature of the valve is evident. The differences in size and density of the striae and areolae are evident between the poles. A single row of areolae is evident on the mantle. (51) external view of rapheless valve. Asymmetry about the transapical axis is evident. Axial area is narrow, straight. Areolae are about the same size and density throughout. (52) rapheless valve, internal view, showing asymmetry about the transapical axis evident, narrow central sternum and elongated areolae. Scale bar $2 \mu \mathrm{m}$. abundant from the type locality (Anbou River) in 1976, by 2007 it was locally extinct. Another genus of freshwater diatoms that can be found in China and Japan is Edtheriotia (KocIOLEK et al. 2016), and there are many genera currently known as endemics in Asia. In fact, there are more endemic genera in Asia than any other continent (KOCIOLEK 2019).

We place our new genus within the Achnanthidiaceae, and that family within the Cymbellales, per the analysis by THOmas et al. (2016). The phylogenetic relationships of some monoraphid genera such as Achnanthidium being part of the Cymbellales supports the classification system of MERESCHKOWSKY (1902) and his group "Monoplacatae". From a biogeographic point of view, Asia is home to the only endemic genera of Cymbellales (Oricymba JütTNER et al. 2010; Celebesia KAPUSTIN et al. 2017; Alveocymba KAPUSTIN et al. 2020). While this is the original presentation of Gomphothidium, (and the discovery of taxa beyond their initial distribution is common in freshwater diatoms), the currently available data suggest that this genus is also endemic to Asia.

Of the 13 genera of freshwater monoraphid diatoms recognized, none of them are endemic to a single continent. This may be due to having lumped species into currently-recognized genera, even though there were revisions of several genera in the last several decades. KocioleK \& Williams (2017) and KocioleK (2019) suggested we many need a more fine-grained taxonomy to further elucidate, describe and interpret biogeographic patterns among genera of freshwater diatom genera.

\section{REFERENCES}

Agardh, C.A. (1830): Conspectus Criticus Diatomacearum. Part 1. - 16 pp., Lundae. Litteris Berlingianis.

Battarbee, R.W. (1987): Diatom analysis. - In: Berglund, B.E. (ed.): Handbook of Holocene Palaeoecology and Palaeohydrology. - pp. 527-570, Wiley, Chichester.

Bukhtiyarova, L. \& Round, F. E. (1996): Revision of the genus Achnanthes sensu lato. Psammothidium, a new genus based on Achnanthidium marginulatum. — Diatom Research 11: 1-30.

EHRENBERG, C.G. (1832): Über die Entwicklung und Lebensdauer der Infusionsthiere; nebst ferneren Beiträgen zu einer Vergleichung ihrer organischen Systeme. - Abhandlungen der Königlichen Akademie der Wissenschaften zu Berlin 1831: 1-154.

Hustedt, F. (1930): Bacillariophyta (Diatomeae). - In: PASChER, A. (ed.): Die Süsswasser-Flora Mitteleuropas, Vol. 10. - 466 pp., Gustav Fischer, Jena.

Jüttner, I.; Krammer, K.; VAn De Vijver, B.; Tuji, A.; Simkhada, B.; Gurung, S. \& Cox, E. J. (2010): Oricymba (Cymbellales, Bacillariophyceae), a new cymbelloid genus and three new species from the Nepalese Himalaya. - Phycologia 49: 407-423.

KARTHICK, B.; TAYlOR, J.C. \& Hamilton, P. B. (2017): Two new species of Achnanthidium Kützing (Bacillariophyceae) from Kolli Hills, Eastern Ghats, India. - Fottea17: 65-77.

Kapustin, D.A.; KulikovskiY, M. \& KocioleK, J.P. (2017): 
Celebesia gen. nov., a new cymbelloid diatom genus from the ancient Lake Matano (Sulawesi Island, Indonesia). - Nova Hedwigia, Beiheft 146: 147-155.

Kapustin, D.A.; KocioleK, J.P.; GlushChenko, A.M. \& Kulikovskiy, M.S. (2020): A rediscovery of Cymbella mirabilis Hustedt, a rare endemic diatom and description of Alveocymba gen. nov. - Diatom Research. doi.org/10.1080/0269249X.2020.1772888.

Kociolek, J.P. (2019): A worldwide listing and biogeography of freshwater diatom genera: A phylogenetic perspective. - Diatom Research 33: 509-534.

Kociolek, J.P.; Balasubramanian, K.; Blanco, S.; Coste, M.; ECTOR, L.; LIU, Y.; KulikovsKIY, M.; LuNDHOLM, N.; Ludwig, T.; Potapova, M.; Rimet, F.; Sabbe, K.; SAla, S.; SAR, E.; TAYLOR, J.; VAN DE ViJVer, B.; Wetzel, C.E.; Williams, D. M.; Witkowski, A. \& Witkowski, J. (2019): DiatomBase. - accessed at http://www.diatombase.org.

Kociolek, J.P.; Theriot, E.C.; Williams, D.M.; Julius, M.; Stoermer, E.F. \& Kingston, J.C. (2015a); Bacillariophyceae: Centric and Araphid Diatoms. - In: Wehr, J.; Sheath, R. \& Kociolek, J.P. (eds): Freshwater Algae of North America, $2^{\text {nd }}$ Edition. - pp. 651-706, Academic Press, NY.

Kociolek, J.P.; Spaulding, S.A; \& Lowe, R.L. (2015b): Bacillariophyceae: The Raphid Diatoms. - In: WeHR, J.; Sheath, R. \& Kociolek, J.P. (eds): Freshwater Algae of North America, $2^{\text {nd }}$ Edition. - pp. 707-770, Academic Press, NY.

KocioleK, J.P. \& Williams, D.M. (2015): How to define a diatom genus? Notes on the creation and recognition of taxa, and a call for revisionary studies of diatoms. Proceedings of the $8^{\text {th }}$ Central European Diatom Meeting. Zagreb, Croatia. - Acta Croatica Botanica 74: 195-210.

Kociolek, J.P.; You, Q.M.; Liu, Q.; Liu, Y \& Wang, Q.X. (In Review): Freshwater diatom biodiversity discovery and description in China: 1848 through 2019. - Phytokeys.

Kociolek, J.P.; You, Q-M.; STEPANeK, J.G.; Lowe, R.L. \& WanG, Q-X. (2016): New freshwater diatom genus, Edtheriotia gen. nov. of the Stephanodiscaceae (Bacillariophyta) from south-central China. - Phycological Research 64: $274-280$

Krammer, K. \& LANGe-Bertalot, H. (1986): Bacillariophyceae. 1. Teil: Naviculaceae. - In: Ettr, H.; Gerfloff, J.; Heynig, H. \& Mollenhauer, D. (eds): Süsswasserflora von Mitteleuropa. - 876 pp., Auflage, Spektrum Akademischer Verlag Heidelberg.

Krammer, K. \& LANGE-BerTaLOT, H. (1991): Bacillariophyceae 4. Teil: Achnanthaceae, Kritische Erganzungen zu Navicu la (Lineolatae), Gomphonema Gesamtliteraturverzeichnis Teil 1-4. - In: Ettr, H.; Gerfloff, J.; Heynig, H. \& Mollenhauer, D. (eds): Süsswasserflora von Mitteleuropa. - 468 pp., Spektrum Akademischer Verlag Heidelberg.

Krammer, K. \& Lange-Bertalot, H. (2004): Bacillariophyceae 4. Teil: Achnanthaceae, Kritische Erganzungen zu Navicu la (Lineolatae), Gomphonema Gesamtliteraturverzeichnis Teil 1-4 (second revised edition). - ETTL, H.; GERFLOFF, J.; Heynig, H. \& Mollenhauer, D. (eds): Süsswasserflora von Mitteleuropa. - 468 pp., Spektrum Akademischer Verlag Heidelberg.

Kulikovskiy, M.S.; Lange-Bertalot, H. \& KuZnetsova, I.V. (2015): Lake Baikal: Hotspot of Endemic Diatoms II. - Iconographia Diatomologica 26.
Kulikovskiy, M.; Lange-Bertalot, H. \& Witkowski, A. (2013): Gliwiczia gen. nov. a new monoraphid diatom genus from Lake Baikal with a description of four species new for science. - Phytotaxa 109: 1-16.

Li, Y.; Williams, D.M.; Metzeltin, D. \& KocioleK, J.P. (2010): Tibetiella pulchra gen. nov. et sp. nov., a new freshwater epilithic diatom from River Nujiang in Tibet, China. - Journal of Phycology 46: 325-330.

Liu, Y.; Kociolek, J.P.; FAN, Y \& KulikovskiY, M. (2018): A new genus of Eunotiales (Bacillariophyta, Bacillariophyceae: Peroniaceae) from southeast Asia, exhibiting remarkable phenotypic plasticity, and evidence for another lineage of monoraphid diatoms. - Phycologia 57: 147-158.

MedLIn, L.K \& KaCZMarSKa, I. (2004): Evolution of the diatoms: V. Morphological and cytological support for the major clades and a taxonomic revision. - Phycologia 43: 245-270.

MereschKowsky, C. (1902): Les types de l'endochrome chez les Diatomées. - Scripta Botanica Horti Universitatis (Imperialis) Petropolitanae. St. Petersburg 21: 1-193.

Monnier, O.; Lange-Bertalot, H.; Hoffmann, L. \& Ector, L. (2007):The genera Achnanthidium Kützing and Psammothidium Bukhtiyarova et Round in the family Achnanthidiaceae (Bacillariophyceae): a reappraisal of the differential criteria. - Cryptogamie, Algologie 28:1 41-158.

Novais, M.H.; JÜTTNER, I.; VAN DE ViJVer, B.; Morais, M.; HoFFMANN, L. \& ECTOR, L. (2015): Morphological variability within the Achnanthidium minutissimum species complex (Bacillariophyta): Comparison between the type material of Achnanthes minutissima and related taxa, and new freshwater Achnanthidium species from Portugal. - Phytotaxa 224: 101-139.

PARR, J.F.; TAFFs, K.H. \& LANE, C.M. (2004): A microwave digestion technique for the extraction of fossil diatoms from coastal lake and swamp sediments. - Journal of Paleolimnology 31: 383-390.

Patrick, R.M. \& ReImer, C.W. (1966): The diatoms of the United States exclusive of Alaska and Hawaii. Volume 1: Fragilariaceae, Eunotiaceae, Achnanthaceae, Naviculaceae. - Monographs of the Academy of Natural Sciences of Philadelphia 13: 1-688.

Peres, F.; Barthes, A.; Ponton, E.; Coste, M.; Ten-Hague, L. \& LE-COHU, R. (2012): Achnanthidium delmontii sp. nov., a new species from French rivers. - Fottea 12: $189-198$

Peres, F.; Cohu, R. L. \& Delmont, D. (2014): Achnanthidium barbei sp. nov. and Achnanthidium costei sp. nov., two new diatom species from French rivers. - Diatom Research 29: 387-397.

RABenhorst, L. (1853): Die Süsswasser-Diatomaceen (Bacillarien) für Freunde der Mikroskopie. - 72 pp., Eduard Kummer, Leipzig.

Round, F.E. \& BAsson, P.W. (1997): A new monoraphid diatom genus (Pogoneis) from Bahrain and the transfer of previously described species $A$. hungarica and $A$. taeniata to new genera. - Diatom Research 12: 347-355.

Round, F.E. \& Bukhtiyarova, L. (1996): Four new genera based on Achnanthes (Achnanthidium) together with a re-definition of Achnanthidium. - Diatom Research 11: 345-361.

Round, F.E.; Crawford, R.M. \& Mann, D.G. (1990): The Diatoms. Biology and Morphology of the Genera. 747 pp., Cambridge University Press.

Thomas, E.; StepaneK, J. \& Kociolek, J.P. (2016): Historical 
and Current Perspectives on the Systematics of the 'Enigmatic' Diatom Genus Rhoicosphenia (Bacillariophyta), with Single and Multi-Molecular Marker and Morphological Analyses and Discussion on the Monophyly of 'Monoraphid' Diatoms. - PLoS One 11: e0152797.

Watanabe, T.; Tuji, A. \& Asai, K. (2008): Epilithic diatom assemblages and two new species Achnanthidium ovatum and Gomphonema yakuensis from Yaku-shima Island, Kagoshima Prefecture, Japan. - Diatom 24: 30-41.

Wojtal, A.Z. (2013): Species composition and distribution of diatom assemblages in spring waters from various geological formation in southern Poland. - Bibliotheca Diatomologica 59: 1-436.

WoJtal, A.Z.; Ector, L.; VAN DE ViJVer, B.; Morales, E.; LANZA,
S.B.; PiateK, J. \& SmiejA, A. (2011): The Achnanthidium minutissimum complex (Bacillariophyceae) in southern Poland. - Algological Studies 136: 211-238.

You, Q.-M.; Kociolek, J.P. \& Wang, Q.-X. (2015): The diatom genus Hantzschia (Bacillariophyta) in Xinjiang province, China. - Phytotaxa 197: 1-14.

Yu, P.; Kociolek, J.P.; You, Q-M. \& Wang, Q-X. (2018): Achnanthidium elongata (Bacillariophyta, Achnanthidiaceae), a new freshwater species from Jiuzhaigou Valley, Southwest of China. - Diatom Research 33: 339-348.

Yu, P.; You, Q-M.; Kociolek, J.P. \& WANG, Q-X. (2019): Three new freshwater species of the genus Achnanthidium (Bacillariophyta, Achnanthidiaceae) from Taiping Lake, China. - Fottea 19: 33-49.

(C) Czech Phycological Society (2021)

Received June 10, 2020

Accepted September 1, 2020 